\title{
FAKTOR-FAKTOR YANG BERHUBUNGAN DENGAN KALA II LAMA
}

\author{
Elvi Destariyani \\ Politeknik Kesehatan Kementerian Kesehatan Bengkulu, Jurusan Kebidanan, \\ Jalan Indragiri Nomor 03 Padang Harapan Kota Bengkulu \\ elvi_destariyani@yahoo.co.id
}

\begin{abstract}
Kalla II long is one of the direct causes of the high maternal mortality rate in the world. In dr. M Yunus in 2011 of women giving birth in 1047 of $196(18.72 \%)$ of the mothers had prolonged second stage of labor, and in 2012 of 1060 women giving birth as $215(20.28 \%)$ mothers had prolonged second stage. The research objective is to determine what are the factors associated with the incidence of prolonged second stage of labor in the CI Space Hospital Midwifery. Dr. M. Yunus Bengkulu city.This study design was a descriptive cross sectional analytic approach. The population is all women giving birth in hospitals M.Yunus Bengkulu in 2012 as many as 1060 people. 290 samples were taken by purposive sampling. Collecting data using secondary data.The results show most women giving birth (51.4\%) multiparous, most maternal (54.1\%) aged less than 20 years and more than 35 years, almost half of women giving birth $(42.8 \%)$ fetal weight more than 4000 grams, and the maternal part $(50 \%)$ experienced a prolonged second stage, and there was a significant association between parity with prolonged second stage, there was a significant association between maternal age with prolonged second stage, there was a significant association between fetal weight with time II time.Under these conditions it is expected that the hospitals Dr.M. Yunus care delivery can minimize the risk of morbidity and maternal and infant mortality by improving the quality and quantity of the proposition, infrastructure and human resources that are reliable and competent.
\end{abstract}

Keywords : Fetal Weight, Kala II Lama, Parity, Age.

Abstrak : Kala II lama merupakan salah satu penyebab langsung dari tingginya AKI di dunia. Di RSUD dr. M Yunus pada tahun 2011 dari 1047 ibu bersalin sebanyak 196 $(18,72 \%)$ orang ibu mengalami persalinan kala II lama, dan pada tahun 2012 dari 1060 ibu bersalin sebanyak $215(20,28 \%)$ ibu mengalami kala II lama. Tujuan penelitian ialah untuk mengetahui faktor-faktor apa sajakah yang berhubungan dengan kejadian kala II lama dalam persalinan di Ruang CI Kebidanan RSUD. Dr. M. Yunus Kota Bengkulu.Desain penelitian ini adalah deskriptif analitik dengan pendekatan cross sectional. Populasi adalah seluruh ibu bersalin di RSUD M.Yunus Bengkulu Tahun 2012 sebanyak 1060 orang.Sampel sebanyak 290 diambil secara purposive sampling.Pengumpulan data menggunakan data sekunder.Hasil analisis menunjukkan sebagian ibu bersalin $(51,4 \%)$ multipara, sebagian besar ibu bersalin $(54,1 \%)$ berumur kurang dari 20 tahun dan lebih dari 35 tahun, hampir sebagian ibu bersalin $(42,8 \%)$ berat badan janinnya lebih dari 4000 gram, dan sebagian ibu bersalin (50\%) mengalami kala II lama, dan ada hubungan yang bermakna antara paritas dengan kala II lama, ada hubungan yang bermakna antara umur ibu dengan kala II lama, ada hubungan yang bermakna antara berat badan janin dengan kala II lama.Berdasarkan hal tersebut diharapkan kepada pihak RSUD Dr.M. Yunus dapat melakukan asuhan persalinan sayang ibu dan dapat meminimalkan resiko angka kesakitan dan kematian ibu dan bayi melalui peningkatan kualitas dan kuantitas saranan dan prasarana serta sumber daya manusia yang handal dan berkompeten.

Kata kunci : Berat Badan Janin, Kala II Lama, Paritas, Umur.

Penyebab tingginya AKI di dunia dan di Indonesia dapat dikelompokkan menjadi dua, yaitu penyebab langsung dan penyebab tidak langsung. Penyebab langsung meliputi: 
perdarahan sebanyak (42 \%), eklamsi sebanyak $(13 \%)$, abortus sebanyak $(11 \%)$, infeksi sebanyak (10\%), partus lama sebanyak (9\%) dan penyebab lain sebanyak (15\%). Sedangkan penyebab tidak langsung diantaranya: faktor pendidikan rendah, sosial ekonomi rendah, system pelayanan kesehatan yang kurang memadai dan lain-lain (Manuaba, 2010). Penyebab langsung dari AKI dapat disebabkan oleh komplikasi pada masa hamil, bersalin dan nifas atau kematian yang disebabkan oleh suatu tindakan atau berbagai hal yang terjadi akibat-akibat tindakan tersebut yang dilakukan selama hamil, bersalin dan nifas (Wiknjosastro, 2010).

Tingginya angka kematian ibu di Indonesia sebagian besar disebabkan oleh timbulnya penyulit persalinan yang tidak dapat segera dirujuk ke fasilitas pelayanan kesehatan yang lebih mampu (Wiknjosastro, 2010). Menurut SDKI (2007), sebanyak $53 \%$ ibu tidak mengalami komplikasi selama persalinan, sedangkan $57 \%$ lainnya mengalami komplikasi. Komplikasi yang sering terjadi yaitu, persalinan lama (kala II lama) sebesar $37 \%$, perdarahan berlebihan sebesar 9\%, dan demam sebesar 7\%, komplikasi kejang 2\% dan KPD lebih dari 6 jam 17\%. Partus lama (kala II lama) merupakan penyebab kematian ibu dan bayi yang utama disusul oleh perdarahan, infeksi, dan eklampsi. Dimana bila suatu persalinan berlangsung lama maka dapat menimbulkan komplikasi-komplikasi baik terhadap ibu maupun terhadap bayi dan dapat meningkatkan angka kematian ibu dan bayi.Salah satu bentuk komplikasi persalinan lama adalah persalinan kala II lama.

Kala II yang lebih lama dari 2 jam untuk primigravida atau 1 jam untuk multipara dianggap abnormal (kala II lama) (Varney, 2008). Dampak kala II lama yang terjadi selama persalinan dapat mengakibatkan komplikasi dalam persalinan seperti kematian ibu yang diakibatkan oleh perdarahan dengan angka kejadian sekitar 34-45 \%, perdarahan pasca persalinan akibat dari retensio plasenta sekitar 16-17\% dan infeksi pasca persalinan sekitar 10-10,5\% (Kemenkes RI, 2010). Selain itu, dampak kala II lama ini juga bisa menimbulkan masalah pada janin seperti gawat janin yang bisa meningkatkan angka kejadian asfiksia dan dapat berakhir pada kematian neonatal (Wiknjosastro, 2010). Partus lama dapat terjadi karena dipengaruhi oleh beberapa faktor antara lain ialah power (kekuatan his dan mengejan), passage (ukuran panggul dan jenis panggul) dan passanger (janin besar, berat badan janin, kelainan letak/presentasi), paritas dan umur ibu, posisi saat ibu bersalin, pemberian analgesia epidural, dan psikis ibu (kelelahan, kecemasan dan kekhawatiran) (Manuaba, 2010).

Ibu yang telah melahirkan anak lebih dari 2 orang, lebih memiliki risiko untuk terjadi kala II lama. Sebab, pada saat kehamilan rahim ibu teregang oleh adanya janin, dan jika ibu sering melahirkan maka rahim akan semakin lemah. Ibu yang telah melahirkan 4 anak atau lebih dapat mengakibatkan kontraksi pada saat persalinan menjadi lemah, sehingga tidak terjadi kemajuan persalinan (Depkes RI, 2009). Oleh karena itu, ibu dengan paritas rendah akan lebih baik jika dibandingkan dengan ibu yang berparitas tinggi dalam kejadian kala II lama (Wiknjosastro, 2010).

Usia ibu hamil terhadap proses kala II persalinan sangat berpengaruh seperti lamanya tahapan kala II (proses pengeluaran bayi). Biasanya persalinan pada primitua dapat terjadi lebih lama, hal ini karena terjadi karena fungsi organ reproduksi sudah menurun.Sedangkan risiko kehamilan pada ibu yang terlalu muda biasanya timbul karena belum siap secara fisik maupun psikis. Pada usia hamil kurang dari 20 tahun atau lebih 35 tahun juga akan terhambat pada penurunan fungsi hormon kewanitaan, karena pada usia tersebut hormon perempuan mengalami penurunan fungsional karena sudah melewati masa puncaknya, yaitu usia 20-30 tahun. Kehamilan di usia kurang dari 20 atau lebih dari 35 tahun akan meningkatkan risiko angka kematian ibu dan janin 4-6 kali lipat dibanding wanita yang hamil dan bersalin di usia 20-30 tahun (Prianggoro, 2009). 
Janin yang mengalami malposisi atau malpresentasi kemungkinan besar mengalami kala II lama (Manuaba, 2010). Menurut hasil penelitian Hastanti (2011), menyebutkan bahwa ada hubungan yang signifikan antara berat badan janin dengan lamanya kala II pada ibu bersalin primiparitas dan pada ibu bersalin multiparitas. Multiparitas dengan berat badan janin >3000 gram merupakan salah satu faktor kala II lama. Berat badan janin >3000 gram rata-rata lama kala II adalah 121 menit dan berat badan janin <3000 gram rata-rata kala II adalah 23 menit.Berbagai penyebab tersebut dapat dicegah dengan pendeteksian komplikasi persalinan secara dini, pengambilan keputusan secara cepat dan tepat serta penanganan yang tepat di tempat rujukan (Depkes, 2003).

Menurut Dharmasetiawani dalam IDAI (2010), menyebutkan bahwa kala II lama merupakan salah satu faktor intrapartum untuk terjadinya asfiksia neonatorum. Asfiksia neonatorum merupakan salah satu faktor yang bisa mengancam kehidupan neonatus.Asfiksia bayi baru lahir menempati penyebab kematian bayi ke 3 di dunia dalam periode awal kehidupan, dengan angka kejadian mencapai 23\% (WHO, 2012).

Berdasarkan rekam medik RSUD Dr. M Yunus Kota Bengkulu yang diperoleh pada 24 April 2014, jumlah persalinan pada tahun 2010 sebanyak 1660 ibu bersalin, sebanyak $261(15,72 \%)$ pada tahun 2011 sebanyak $1047 \mathrm{ibu}$ bersalin, dan sebanyak 196 $(18,72 \%)$ orang ibu mengalami persalinan kala II lama. Pada tahun 2012 sebanyak 1060 ibu bersalin, dan sebanyak 215 $(20,28 \%)$ ibu bersalin yang mengalami komplikasi kala II lama. Penelitian ini bertujuan untuk mengetahui faktor-faktor kejadian kala II lama dalam persalinan di Ruang CI Kebidanan RSUD. Dr. M .Yunus Kota Bengkulu tahun 2014.

\section{BAHAN DAN CARA KERJA}

Penelitian ini menggunakan metode penelitian analitik dengan pendekatan secara potong silang. Dimana pengumpulan data variabel independen (umur, paritas, berat badan janin) dan variabel dependen (kala II lama) dilakukan sekaligus pada saat yang sama. Populasi dalam penelitian ini adalah seluruh ibu bersalin yang ada di buku register ibu bersalin Ruang CI Kebidanan RSUD M.Yunus Bengkulu Tahun 2012 sebanyak 1060 orang. Sampel sebanyak 290 orang diambil secara purposive sampling.. Analisis data menggu-nakan uji chi-kuadrat.

\section{HASIL}

Tabel 1. Distribusi Frekuensi Paritas, Umur, Berat Badan Janin dan Kala II Lama

\begin{tabular}{ccc}
\hline Variabel & F & \% \\
\hline Paritas & & \\
Primipara/Grandemultipara & 152 & 52,4 \\
Multipara & 138 & 47,6 \\
Umur & & \\
<20 Tahun dan $\geq 35$ Tahun & 134 & 46,2 \\
20-35 Tahun & 156 & 53,8 \\
Berat Badan Janin & 124 & 42,8 \\
$\quad>4000$ & 166 & 57,2 \\
$\quad$ <4000 & 145 & 50 \\
Kala II Lama & 145 & 50 \\
Kala II Lama & & \\
Tidak Kala II Lama &
\end{tabular}

Berdasarkan tabel 1 diketahui bahwa dari 290 ibu bersalin, sebagian besar $(52,4 \%)$ primipara dan grandemultipara, sebagian besar $(53,8 \%)$ berumur $20-35$ tahun, sebagian besar $(57,2 \%)$ berat badan janinnya $\leq 4000$ gram, dan sebagian ibu bersalin (50\%) mengalami kala II lama.

Berdasarkan Tabel 2 diketahui bahwa dari 152 ibu bersalin primipara/grandemultipara hampir seluruhnya $(83,6 \%)$ mengalami kala II lama, dan dari 138 ibu bersalin multipara sebagian kecil (13\%) mengalami kala II lama yang disebabkan oleh usia ibu ( $<20$ tahun dan $>35$ tahun), berat badan janin $>4000$ gram. Hasil uji statistik menunjukkan nilai $p=0,000<\alpha=0,05$ yang berarti ada hubungan yang bermakna antara paritas dengan kala II lama.

Hasil pada tabel 2 diketahui bahwa dari 134 ibu bersalin berusia <20 tahun dan $>35$ tahun hampir seluruh $(91 \%)$ mengalami kala II lama, dan dari 156 ibu bersalin berusia 20-35 tahun sebagian kecil $(14,7 \%)$ mengalami kala II lama yang disebabkan oleh berat janin $>4000$ gram dan paritas ibu. Hasil uji statistik menunjukkan nilai $p=0,000<\alpha=0,05$ yang berarti ada hubungan 
yang bermakna antara umur ibu dengan kala II lama.

Tabel 2 juga menunjukan bahwa dari 125 ibu bersalin yang berat badan janinnya $>4000 \mathrm{gr}$, hampir seluruh $(87,9 \%)$ mengalami kala II lama, dan dari 166 ibu bersalin yang berat badan janinnya $\leq 4000 \mathrm{gr}$ sebagian kecil $(21,7 \%)$ mengalami kala II lama yang terjadi karena faktor paritas dan usia ibu (< 20 tahun dan $>35$ tahun). Hasil uji statistik menunjukkan nilai $p=0,000<\alpha=0,05$ yang berarti ada hubungan yang bermakna antara berat badan janin dengan kala II lama.

Tabel 2. Perbedaan Paritas dengan kala II Lama

\begin{tabular}{|c|c|c|c|c|}
\hline \multirow{3}{*}{$\begin{array}{c}\text { Variabe } \\
1\end{array}$} & \multicolumn{2}{|c|}{ Kala II Lama } & \multirow[b]{2}{*}{ Total } & \multirow{3}{*}{$\begin{array}{c}\text { Nilai } \\
\mathbf{p}\end{array}$} \\
\hline & $\begin{array}{c}\text { Kala II } \\
\text { Lama }\end{array}$ & $\begin{array}{l}\text { Tidak Kala } \\
\text { II Lama }\end{array}$ & & \\
\hline & $\%$ & $\%$ & $\%$ & \\
\hline
\end{tabular}

\begin{tabular}{|c|c|c|c|c|c|c|c|}
\hline \multicolumn{8}{|l|}{ Paritas } \\
\hline $\begin{array}{l}\text { Primipara/ } \\
\text { Grandemul } \\
\text { tipara }\end{array}$ & 127 & 83,6 & 25 & 16,4 & 152 & 100 & \multirow[t]{2}{*}{0,000} \\
\hline Multipara & 18 & 13 & 120 & 87 & 138 & 100 & \\
\hline \multicolumn{8}{|l|}{ Umur } \\
\hline $\begin{array}{l}<20 \text { th } \\
\text { dan }>35 \\
\text { th }\end{array}$ & 122 & 91 & 12 & 9 & 134 & 100 & \multirow[t]{2}{*}{0,000} \\
\hline $20-35$ th & 23 & 14,7 & 133 & 85,3 & 156 & 100 & \\
\hline \multicolumn{8}{|c|}{ Berat Badan Janin } \\
\hline$>4000 \mathrm{gr}$ & 109 & 87,9 & 15 & 12,1 & 124 & 100 & \multirow{2}{*}{0,000} \\
\hline$\leq 4000 \mathrm{gr}$ & 36 & 21,7 & 130 & 78,3 & 166 & 100 & \\
\hline
\end{tabular}

Uji statistik : Chi-square

\section{PEMBAHASAN}

\section{Hubungan Paritas dengan Kala II Lama}

Hasil penelitian diketahui dari $152 \mathrm{ibu}$ bersalin primipara/grandemultipara menunjukkan hampir seluruh $(83,6 \%)$ mengalami kala II lama. Dikatakan sebagai kala II lama apabila proses persalinan kala II berlangsung lebih dari 2 jam (Wiknjosastro, 2010). Kala II yang lebih lama dari 2 jam untuk primigravida atau 1 jam untuk multipara dianggap abnormal (Varney, 2008).

Hasil uji statistik menunjukkan ada hubungan yang bermakna antara paritas dengan kala II lama.Semakin banyak jumlah bayi yang telah dilahirkan, persalinan secara progresif lebih lama. Hal ini diduga akibat keletihan pada otot-otot uterus.
Menurut hasil penelitian Supriyati (2001), menunjukkan bahwa ada hubungan yang bermakna antara paritas dengan distosia persalinan. Ibu hamil dengan paritas 1 atau lebih dari 5 memiliki resiko untuk terjadi distosia 3,86 kali lebih besar disbandingkan dengan ibu hamil dengan paritas 2 sampai 5.

Penelitian juga didapatkan bahwa sebagian kecil $(13 \%)$ ibu bersalin multipara juga mengalami kala II lama. Hal ini terjadi karena ada faktor lain yang mempengaruhi persalinan kala II lama yaitu umur, interval kelahiran, ketuban pecah dini, penolong persalinan (Analgesia Epidural, dan posisi Ibu), dan psikis ibu (kecemasan, kelelahan, kekhawatiran) (Saifudin, 2010).

\section{Hubungan Umur Ibu dengan Kala II La-ma}

Hasil penelitian menunjukkan dari 134 ibu bersalin berusia $<20$ tahun dan $>35$ tahun, hampir seluruh $(91 \%)$ mengalami kala II lama.Usia ibu di bawah 20 tahun atau diatas 35 tahun mempredisposisi wanita terhadap sejumlah komplikasi. Usia dibawah 20 tahun insiden preeklampsia sedangkan usia diatas 35 tahun meningkatkan insiden hipertensi kronis dan persalinan yang lama (Varney, 2008).

Pada umur kurang dari 20 tahun, organ-organ reproduksi belum berfungsi dengan sempurna, sehingga bila terjadi kehamilan dan persalinan akan lebih mudah mengalami komplikasi. Faktor risiko untuk persalinan sulit pada ibu yang belum pernah melahirkan pada kelompok umur ibu dibawah 20 tahun dan pada kelompok umur diatas 35 tahun adalah 3 kali lebih tinggi dari kelompok umur reproduksi sehat (20-35 tahun) (Wiknjosastro, 2010).

Hasil uji statistik menunjukkan ada hubungan yang bermakna antara umur ibu dengan kala II lama. Hasil penelitian ini sejalan dengan penelitian Mail (2011), bahwa dari 25 responden didapatkan responden yang hamil pada usia tidak berisiko paling banyak mengalami lama kala II normal yaitu 7 responden (28\%) sedangkan responden yang hamil pada usia berisiko tinggi kehamilan paling banyak mengalami lama kala II 
yang tidak normal yaitu sebanyak 11 responden $(44 \%)$.

Pada penelitian juga didapatkan bahwa sebagian kecil ibu bersalin $(14,7 \%)$ yang berusia 20-35 tahun juga mengalami kala II Lama. Ini terjadi karena terdapat faktor lain yang mempengaruhi persalinan kala II lama yaitu paritas, interval kelahiran, ketuban pecah dini, penolong persalinan (Analgesia Epidural, dan posisi Ibu), dan psikis ibu (kecemasan, kelelahan, kekhawatiran) (Saifudin, 2010).

\section{Hubungan Berat Badan Janin dengan Kala II Lama}

Hasil penelitian menunjukkan dari 124 ibu bersalin yang berat badan janinnya $>4000$ gr, sebagian besar $(87,9 \%)$ mengalami kala II lama. Berat badan janin dapat mempengaruhi proses persalinan kala II. Berat neonatus pada umumnya $<4000$ gram dan jarang mebihi 5000 gram (Wiknjosastro, 2007). Pada persalinan cukup bulan (aterm) dengan lama kehamilan 37-42 memiliki berat anak >2500 gram (Wirakusumah, dkk, 2005).

Janin yang mempunyai berat lebih dari 4000 gram memiliki kesukaran yang ditimbulkan dalam persalinan adalah karena besarnya kepala atau besarnya bahu.Bagian paling keras dan besar dari janin adalah kepala, sehingga besarnya kepala janin mempengaruhi berat badan janin. Oleh karena itu sebagian ukuran kepala digunakan Berat Badan (BB) janin (Mochtar, 2010).

\section{DAFTAR RUJUKAN}

Athoillah. 2010. Dasar - Dasar Manajemen. Editor, CV pustaka Setia, Bandung

Azwar, 1996. Pengantar Administrasi Kesehatan. Editor, PT. Binarupa Aksara, Jakarta

Brantas. 2009. Dasar - Dasar Manajemen. Editor, Alfabeta, Bandung

Depkes RI, 2009. Pedoman Pelaksanaan Kelas Ibu Hamil, . Editor, Jakarta.

G. Terry. R. 2009. Prinsip - Prinsip Manajemen Editor, Bumi Aksara, Jakarta

Gilbert, Manajemen Jilid 1. Editor, Bhuana Ilmu Populer, Jakarta, 1996.

Handoko. 2009. Manajemen Editor, BPFEYogyakarta, Yogyakarta

Hasibuan. 2009. Manajemen Sumber Daya Manusia. Editor, Bumi Aksara, Jakarta
Hasil uji statistik menunjukkan ada hubungan yang bermakna antara berat badan janin dengan kala II lama. Implikasi makrosomia bagi ibu melibatkan distensi uterus, yang menyebabkan peregangan yang berlebihan pada serat-serat uterus, menyebabkan disfungsional persalinan, kemungkinan rupture uterus, dan peningkatan insiden perdarahan post partum.Persalinan dapat menjadi lebih lama dan tindakan operasi pada saat melahirkan menjadi lebih memungkinkan (Hamilton, 2005).

\section{KESIMPULAN}

Berdasarkan penelitian dapat disimpulkan bahwa Ibu bersalin di RSUD dr. M. Yunus Bengkulu, sebagian mengalami kala II lama, hampir sebagian multipara, sebagian besar berumur 20-35 tahun, dan sebagian besar berat badan janinnya <4000 gram, ada hubungan paritas dengan kala II Lama di RSUD dr M Yunus Bengkulu, ada hubungan Umur ibu dengan kala II lama di RSUD dr M Yunus Bengkulu dan ada hubungan berat badan janin dengan kala II lama di RSUD dr M Yunus Bengkulu.

Diharapkan pihak RSUD Dr. M. Yunus dapat memfasilitasi bidan untuk mengikuti pelatihan penanganan kegawatdaruratan pada ibu bersalin secara kontinyu dan menyediakan sarana dan prasarana yang lengkap untuk melakukan penatalaksanaan kala II lama dengan cepat dan tepat.

Moekijat. 2000. Fungsi - fungsi manajemen. Editor, Bandung, 2000

Muninjaya. 2004. Manajemen Kesehatan. Editor, EGC, Jakarta

Robbins. 2010. Manajemen jilid 1. Editor, Erlangga, Jakarta,.

Siagian. P. 2000. Fungsi fungsi Manajerial. Editor, Bumi Aksara., Jakarta

Siswanto. B. 2010.Pengantar Manajemen. Editor, Bumi Aksara, Jakarta.

Wijono. 2008. Manajemen Kesehatan Ibu Dan Anak Prinsip Dan Srategi Pendekatan Komunitas. Editor, Duta Prima Airlangga, Surabay 